\title{
A Study of the Impact of Dress Model Technology on Intention to Buy on Evolving e-CRM European Union Web Sites
}

\author{
James Lawler and Anthony Joseph \\ Pace University, New York City, \\ NY, USA
}

jlawler@pace.edu ajoseph2@pace.edu

\author{
Pascale Vandepeutte \\ University of Mons-Hainaut, \\ Mons, Belgium
}

pascale.vandepeutte@umh.ac.be

\begin{abstract}
This study analyzes design factors that contribute to the intention of goal-focused consumers to buy apparel on European Web sites that have dress model technology. Factors from academic literature of perceived ease of use, perceived usefulness, media richness of technology, decision satisfaction, and behavioral intention to return are especially examined in the study. The results confirm earlier exploratory studies by the authors in 2007 and 2006 positing media richness of dress model technology as less important in intention to buy than the other factors and begin to indicate that the technology is not important in facilitating electronic customer relationship management (e-CRM) on the Web. The study was conducted as an experiment with adult goalfocused students of a leading Belgian business university as proxy shoppers of the Web sites. The results of this study will benefit both European and American e-Business designers and managers considering direction and further investment in multimedia technologies on apparel Web sites.
\end{abstract}

Keywords: apparel industry, business-to-consumer (B2C), dress model technology, e-Business, electronic customer relationship management (e-CRM), and European Union

\section{Introduction}

Electronic business (e-Business) continues to benefit from the growth in the number of consumers on the Internet, which is currently estimated to be $750+$ million globally, a $10 \%$ increase from 2006 ("Worldwide internet audience," 2007). The number of consumers on the Internet in America in contrast is estimated to be $150+$ million, $20 \%$ of the $750+$ million ("Worldwide internet audience," 2007). From a 2006 global information technology index of 122 countries of the World Economic Forum, countries in Europe are considered to be applying the benefits of infor-

Material published as part of this publication, either on-line or in print, is copyrighted by the Informing Science Institute. Permission to make digital or paper copy of part or all of these works for personal or classroom use is granted without fee provided that the copies are not made or distributed for profit or commercial advantage AND that copies 1) bear this notice in full and 2) give the full citation on the first page. It is permissible to abstract these works so long as credit is given. To copy in all other cases or to republish or to post on a server or to redistribute to lists requires specific permission and payment of a fee. Contact Publisher@InformingScience.org to request redistribution permission. mation and communication technology

(ICT) and of the Web at competitively high levels (Scott, 2007). Though America improved to be first from sixth in the index since 2006 (O'Connor, 2007), the bulk of the countries in the highest tenth of the index is European (Scott). Emerging is an ecosystem of innovation in Europe ("World's most innovative countries," 2007). Enabling benefits of e-Business and technology is 
the connectivity of the Web, as displayed in Figure 1, from a study of the European Commission on countries in the European Union.

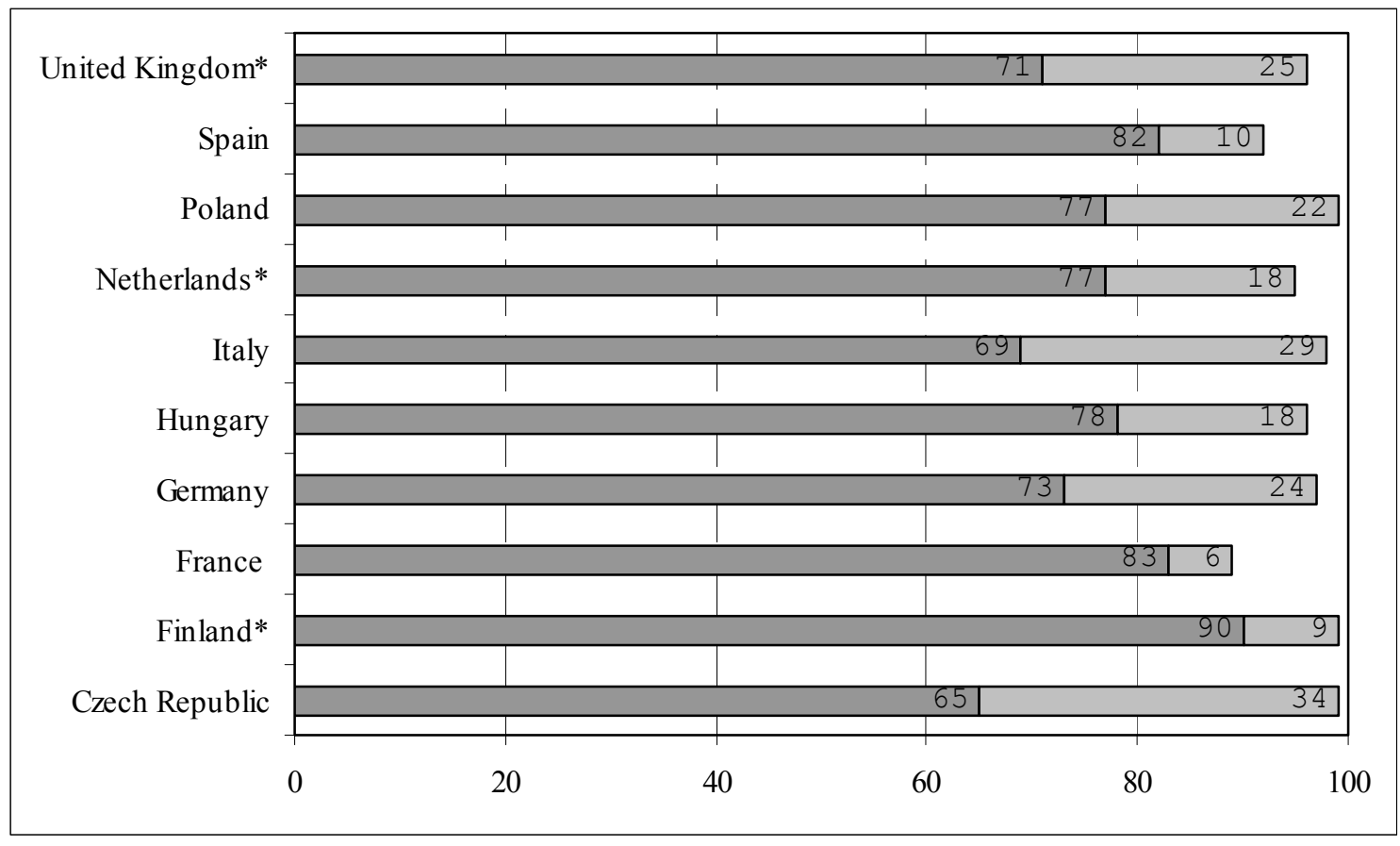

Figure 1: European Union e-Business Connectivity Index

Broadband $\square$ Dial-up

* World Economic Forum Global Information Technology Index of Highest 10 Countries, 2006 (Percentage of $\mathrm{n}=7237$ Firms with Broadband or Dial-Up) [Adapted]

Source: European Commission, 2006. p. 14.

Networked readiness is enabling a foundation for competitiveness in business-to-consumer (B2C) and customer relationship management (CRM) in countries of the European Union. Finland, France, Germany, Poland, and the United Kingdom exceed other European Union countries in indicators of B2C of the European Commission, as displayed in Figure 2.

Countries in the European Union having high networked readiness furnish benefits for consumers and firms to flourish in a B2C global economy (Carlin, 2007). Estimates indicate increased competitiveness in $\mathrm{B} 2 \mathrm{C}$, in electronic customer relationship management (e-CRM) interaction with customers on the Web, and in ICT by firms in the European Union in 2007 - 2011 ("Information communication technology," 2007).

This growth is contributing to creative design of Web sites that differentiate experiences for consumers in the European Union to buy on the Web, which is evidence of technology as a continued enabler in differentiation (Fitzsimmons \& Fitzsimmons, 1997). Experiences have to be perceived to be fully functional, engaging, and compelling in order to convert consumers into customers (Pullman \& Gross, 2004). Such experiences form a foundation for one-to-one relationship marketing and service on the Web that impact the intention of customers to continue to buy on the differentiated sites (Chen, Chen, \& Kazman, 2007, pp. 2-3).

Innovation in the design of buying experiences and relationships and in the integration of technology may give an edge in competitiveness to especially apparel dress model European Union 


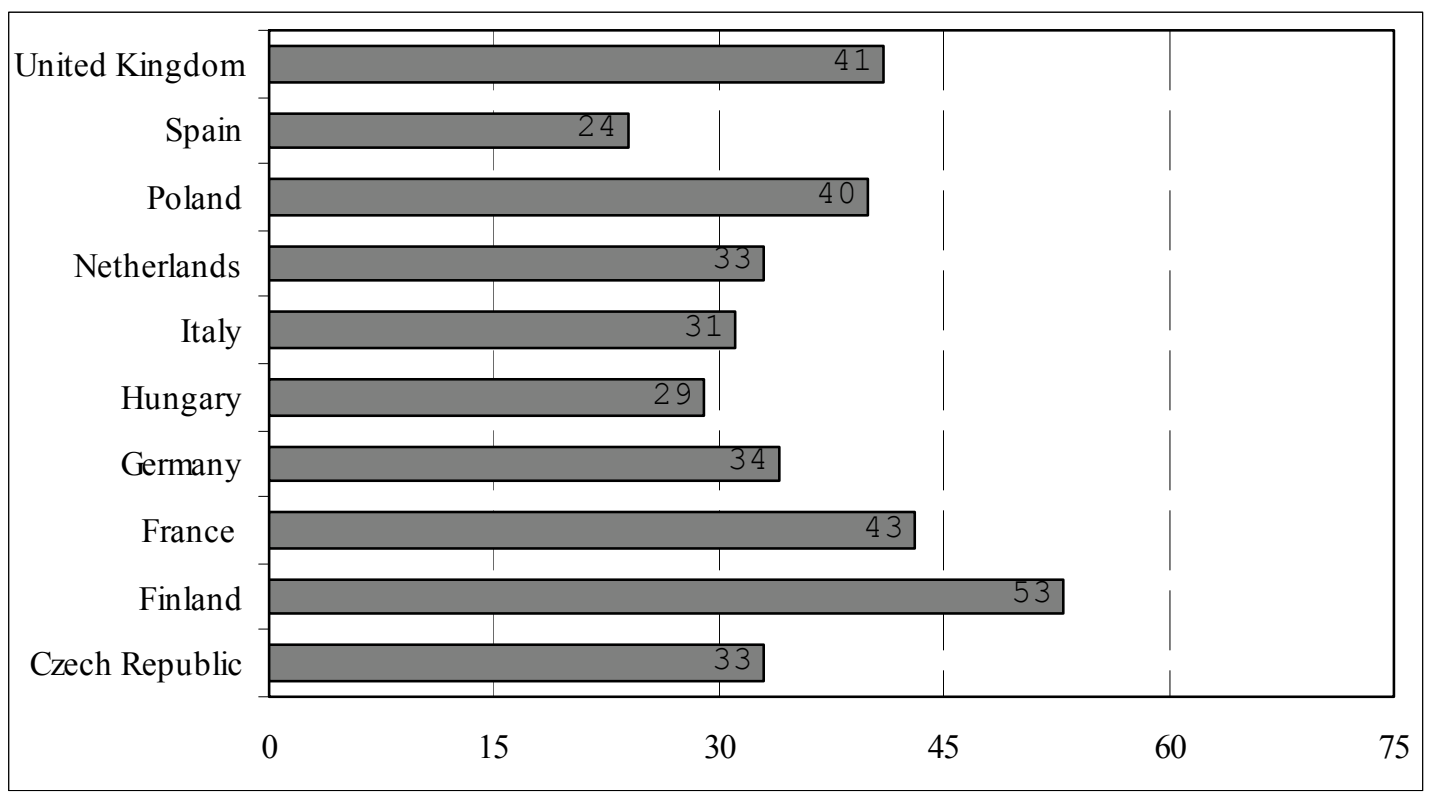

Figure 2: European Union Business-to-Consumer (B2C) Index

(Percentage of $\mathrm{n}=7237$ Firms with On-Line Orders) [Adapted] Source: European Commission, 2006, p. 27.

Web sites, if the design and integration on the sites furnish discernable differential for the customers, which is the focus of this study.

\section{Literature Review}

Firms in Europe and in America continue to differentiate apparel Web sites by enhancing dress models of their products with media richness (Lawler \& Joseph, 2006; Lawler, Vandepeutte, \& Joseph, 2007). Literature distinguishes richness as an enabling factor in a mediated environment that affects consumer decisions to buy the products (Bezjian-Avery \& Calder, 1998; Coyle \& Thorson, 2001; Klein, 2003) and be loyal to the sites (Gharbi \& Soltani, 2007). Richness is defined as multimedia representations of products for enhancing not only the pleasure of shopping but also the process of shopping on these sites and stimulating the senses of shoppers (BezjianAvery \& Calder, 1998; Coyle \& Thorson, 2001; Klein, 2003). Richness is evident in consumer customized 3D dynamic imaging of products on models (Olson, 2007) and in graphical representations of shoppers (Wolfendale, 2007), improved with multimedia technology. Such models and representations evolved from impersonal default 2D mannequins (Greenemeier, 2005) on apparel Web sites. Interactive features of the models and representations may affect experiences to buy the products (Fiore \& Jin, 2003; Kim \& LaRose, 2004; Li, Daugherty, \& Biocca, 2001). Interactivity may be perceived to be more realistic (Hoffman \& Novak, 1996; Novak, Hoffman, \& Yung, 1999) and potentially recreational and social (Hof, 2007) on the sites than interaction in the physical stores. Media rich systems may be improved by broadband and digital imaging that integrate Asynchronous Javascript and XML (AJAX) (Danziger, 2006) and Flash on product screens, P2P streaming of product shows (Schonfeld, 2007), and potentially Entropia Universe, Second Life and There simulations (Hemp, 2006b; McConnon, 2007; Newitz, 2007) of stores on vivid 3D Net Web sites. Investment is justified in the perception that richness of technology is important in intention to buy on apparel Web sites if not important in loyalty to the sites. Justification is evident in other initiatives in integrating Web-enabled "magic mirror" modeling in 
stores (Schneider, 2007), popular product videos (Cane, 2007) and real and virtual tours of stores on the Web (Eisenberg, 2007).

Literature in the academic field is extensive however in indication that further factors than richness of technology may impact and be important in intention to buy on Web sites. Factors of perceived ease of use and perceived usefulness from the technology acceptance model (TAM) (Davis, 1989; Venkatesh, Morris, Davis, \& Davis, 2003) may be important in influencing consumers to interface with the functionality of media rich shopping systems on dress model sites. Ease of use may be defined as the extent of customer perception of the freedom in effort and navigation on the sites. Usefulness may be defined as the extent of perception of the functionality or the steps in enhancing the process of shopping on the sites. In this study, the definition of usefulness includes the existence of information on products that might be useful to the customer, though TAM obscures this. Information on products is important in a study of media richness, as sites may be designed to focus less on the information and more on the glitz of multimedia technology. Both of these factors of usefulness and ease of use are documented extensively however in the academic literature (Sharp, 2006). Decision satisfaction, defined as the extent of customer perception of the service and support, may be important in intention to buy (Garrity, Glassberg, Kim, Sanders, \& Shin, 2005). Behavioral intention to return to sites, as the extent of perception of the sites in enhancing and using the process of shopping (Davis, 1989), is a factor that may be important in continued intention to buy products on the sites. Pre-attitude and post-attitude to shopping on sites, defined as the extent of favorable customer preference to buy and continue to buy on the sites, may be also important in feeling (Cheung, Chan, \& Limayem, 2005) in intention to buy products on sites.

Other factors might include consumer perceptions of the firm and of the products, quality of the products, prices, risk and security, and trust on the sites. They might even include perceptions of fun (Goldsmith, 2000) and playfulness (Liu, Armett, Capella, \& Taylor, 2001) on the sites.

Though the factor of richness of media technology may be important in the intention to buy on dress model sites, research into the earlier inherently non-technological factors might contribute insight into the relative importance of these factors in design of the sites in contrast to richness. Research might help designers in improving the factor mix of non-richness and richness of technology on the sites for goal-focused consumers that desire to do less hedonic or experiential tasks and more utilitarian tasks. Such help is important in improving dress model shopping sites, neither utilitarian nor hedonic but hybrid in tasks (Valacich, Parboteeah, \& Wells, 2007), in order to satisfy non-goal focused and goal-focused shopping tasks.

Research into the media richness of dress model technology is documented in exploratory studies of European and American apparel Web sites by the authors of this study in 2007 (Lawler et al., 2007) and 2006 (Lawler \& Joseph, 2006). Results of the studies indicate that the factor of richness of technology is less important than non-technological factors in the intention of goalfocused knowledgeable customers to buy on apparel Web sites. Factors of control and freedom, product selection, lack of sociality, availability of information and accessibility and convenience identified in the studies from a narrow niche of the practitioner literature (Wolfinbarger \& Gilly, 2001 ) indicate more importance than the hype of richness of technology in the intention of goalfocused customers to buy products on Web sites. Practitioner requirements (Byrnes, 2007) and studies further indicate the importance of non-technological factors (Nielsen, 2007) on Web 1.0 sites, and the non-importance of Web 2.0 technological trends, as consumers may form flash impressions of sites based frequently on non-technological factors (McCoy, Everard, Polak, \& Galletta, 2007) and surf to other sites on which they buy the products (Srinivasan, Anderson, \& Ponnavolu, 2002). These studies form a foundation for designing evolving e-CRM functionality that integrates media richness of technology on European Union apparel sites, so that consumers buy and customers continue to buy on these sites. 
Research into e-CRM indicates the importance of marketing, sales, and service enabled by technology (Bergeron, 2001) that impacts the intention to buy on sites, such as apparel Web sites. Design of e-CRM service on sites is evolving from low touch technology, such as e-mail, frequently asked questions and 1-800 telephoning, to high touch tools, such as instant chat, social networking and telephony, enabling fulfillment, and interaction (Chen et al., 2007, p. 3), so that consumers buy products on the sites. Features of an interface of information technology are indicated to be important in response (Wailgum, 2006) and service (Massad, Heckman, \& Crowston, 2006) on sites. Features of e-CRM sales and marketing are enabling personal interactivity if not service based on data mining and data warehousing technologies (Chen et al., 2007, p. 3), so that customers continue to buy on the sites. Functionality is evident on highly rated sites, such as www.bonprix-shop.be or www.landsend.com and www.zappos.com (Durst, 2006; McDonald, 2006).

Functionality of e-CRM is founded on a design of factors of perceived ease of use and perceived usefulness of marketing, sales, and service technologies, or on the perceived touch (Chen et al., 2007, pp. 4-5) of the site technologies, which may or may not be favorable in initiation of customer relationship or in the intention to buy or continue to buy (Brinker, 2007). Functionality of marketing, sales, and service in e-CRM may or may not be helped by media richness in intention to buy or continuing to buy in a relationship. Richness may help in buying but not in continuing to buy in loyal relationship. Though the factor of media richness of technology is indicated to be less important relative to non-technological factors for goal-focused customers in the 2007 (Lawler et al., 2007) and 2006 (Lawler \& Joseph, 2006) studies, richness is still a factor that is important individually in the intention to buy on European apparel Web sites, as the sites have to have a mix of technological and non-technological factors tailored to hedonic and utilitarian tasks (Van Der Heijden, 2004). Richness may be more important in the introduction of new social media (Rayport, 2007) and consumer interface (Mitchell, 2006) technologies that might improve dress model sites. Study of media richness of technology in e-CRM might help e-Business managers in the European Union in evaluating further investment on apparel Web sites.

This study extends the factors of control and freedom, product selection, lack of sociality, availability of information and convenience and accessibility, from the narrow dimension of generally practitioner literature of the studies in 2007 (Lawler et al., 2007) and 2006 (Lawler \& Joseph, 2006). Factors of perceived ease of use, perceived usefulness, decision satisfaction, and behavioral intention to return, from primarily academic literature, furnish a broader dimension for evaluating the relative importance of richness. They furnish a foundation for further evaluating the feature functionalities of e-CRM systems in importance in the initiation of customer relationship on European Union dress model sites. This study helps e-Business managers in the European Union as firms investigate future technologies for interactivity on the Web (Orman, 2007) that may impact and be important in intention to buy and to continue to buy on apparel dress model sites. This study may be helpful in improving return-on-investment (ROI) (Pratt, 2007) on sites that intelligently integrate richness of media technology and e-CRM. The factors of this study are summarized in Table 1: 
Table 1: Factors of Perception in Intention to Buy of Goal-Focused Shoppers on European Web

\begin{tabular}{|c|c|c|}
\hline Factor & Definition & Primary Sources \\
\hline Pre-Attitude to Web Shopping & $\begin{array}{l}\text { Extent of Favorable Preference to } \\
\text { Buy Apparel Products on Dress Mod- } \\
\text { el Sites of Web }\end{array}$ & Cheung, Chan, \& Limayem, 2005 \\
\hline Perceived Ease of Use of Web Site & $\begin{array}{l}\text { Extent of Perception of Freedom in } \\
\text { Effort and Navigation on Dress Mod- } \\
\text { el Sites }\end{array}$ & Davis, 1989 \\
\hline Perceived Usefulness of Web Site & $\begin{array}{l}\text { Extent of Perception of Functionality } \\
\text { in Enhancing Process of Apparel } \\
\text { Shopping on Dress Model Sites }\end{array}$ & Davis, 1989 \\
\hline $\begin{array}{l}\text { Richness of Media Technology on } \\
\text { Web Site }\end{array}$ & $\begin{array}{l}\text { Extent of Perception of Multimedia } \\
\text { Representations of Products on Dress } \\
\text { Model and Picture Sites in Enhancing } \\
\text { Process of Apparel Shopping on Sites }\end{array}$ & $\begin{array}{l}\text { Lawler, Vandepeutte \& Joseph, } \\
\text { 2007; Lawler \& Joseph , 2006; } \\
\text { Klein, 2003; Coyle \& Thorson, 2001; } \\
\text { Bezjian-Avery \& Calder, } 1998\end{array}$ \\
\hline Decision Satisfaction with Web Site & $\begin{array}{l}\text { Extent of Perception of Support and } \\
\text { Tools on Dress Model Sites in En- } \\
\text { hancing Process of Apparel Shopping } \\
\text { on Sites }\end{array}$ & $\begin{array}{l}\text { Garrity, Glassberg, Kim, Sanders, \& } \\
\text { Shin, } 2005\end{array}$ \\
\hline $\begin{array}{l}\text { Behavioral Intention to Return to } \\
\text { Web Site }\end{array}$ & $\begin{array}{l}\text { Extent of Favorable Perception of } \\
\text { Dress Model Sites in Enhancing and } \\
\text { Using Information and Process of } \\
\text { Apparel Shopping on Sites }\end{array}$ & $\begin{array}{l}\text { Venkatesh, Morris, Davis, \& Davis, } \\
2003\end{array}$ \\
\hline Post-Attitude to Web Shopping & $\begin{array}{l}\text { Extent of Favorable Preference to } \\
\text { Continue to Buy Apparel Products on } \\
\text { Dress Model Sites of Web }\end{array}$ & Cheung, Chan, \& Limayem, 2005 \\
\hline
\end{tabular}

The focus of this study is to evaluate if not finalize the importance or non-importance of richness of media technology as a design factor relative to the mix of non-technological factors of perceived ease of use, perceived usefulness, decision satisfaction, and behavioral intention to return, in the intention of European goal-focused knowledgeable customers to buy and to continue to buy products on European Union dress model and picture sites. The hypothesis of the study is that richness of technology is not as important as the other factors. The focus of a future study will be to evaluate the importance of e-CRM functionalities of marketing, sales, and service in initiation of relationship on the European Union dress model sites and in intention to return to the sites. Such study will further evaluate the results of a model on perceived touch of e-CRM options and technologies as a predictor on intention to return to sites (Chen et al., 2007, pp. 6-7). Fresh insight into the non-importance or importance of richness of media technology and e-CRM technologies may be helpful in informing managers of improved design strategy on the Web, at a time when the European Union is expanding funding for research in ICT (Blau, 2007; "European Union to invest \$9 billion," 2006) and next generation multimedia technologies (Gardner, 2006). This study is timely.

\section{Methodology}

The experiment of this study continues from a base of analysis that began as a project in the Strategies for e-Commerce Technologies course, at Pace University in America in 2003, and continued as assigned projects in an e-Business Concepts and Applications course, at the University of Mons-Hainaut in Belgium into 2007, as summarized in Table 2 and in Figure 3. 
Table 2: Research Methodology on Dress Model Technology

\begin{tabular}{|c|c|c|c|}
\hline & American Dress & \multicolumn{2}{|c|}{ European Dress Model Study } \\
\hline Study & $\begin{array}{l}\text { Lawler \& Joseph, } \\
2006\end{array}$ & Lawler, Vandepeutte \& Joseph, 2007 & $\begin{array}{c}\text { Lawler, Joseph, \& Vandepeutte, } \\
2008 \text { (this paper) }\end{array}$ \\
\hline $\begin{array}{l}\text { Periods of } \\
\text { Study }\end{array}$ & $\begin{array}{c}\text { Spring } 2004 \\
\text { Summer } 2004 \\
\text { Fall } 2004 \\
\text { Spring 2005 }\end{array}$ & Spring 2006 & Spring 2007 \\
\hline $\begin{array}{l}\text { Shopping } \\
\text { Sites }\end{array}$ & 19 American Sites & 10 European Sites & 18 European Sites \\
\hline $\begin{array}{l}\text { Student } \\
\text { Subjects }\end{array}$ & $\begin{array}{l}68 \text { Graduate Students } \\
\text { of Pace University, } \\
\text { USA }\end{array}$ & $\begin{array}{c}27 \text { Post-Graduate, Graduate and } \\
\text { Undergraduate Students of } \\
\text { University of Mons-Hainaut, } \\
\text { Belgium }\end{array}$ & $\begin{array}{c}36 \text { Graduate and Undergraduate } \\
\text { Students of University of Mons- } \\
\text { Hainaut, Belgium }\end{array}$ \\
\hline $\begin{array}{l}\text { Average Age } \\
\text { \& Gender of } \\
\text { Subjects }\end{array}$ & $\begin{array}{c}27 \text { Years } \\
\text { 41\% Female } \\
59 \% \text { Male }\end{array}$ & $\begin{array}{c}22 \text { Years } \\
\text { 52\% Female } \\
\text { 48\% Male }\end{array}$ & $\begin{array}{c}25 \text { Years } \\
\text { 56\% Female } \\
44 \% \text { Male }\end{array}$ \\
\hline $\begin{array}{l}\text { Frequency of } \\
\text { Subjects on } \\
\text { Web }\end{array}$ & 34 Hours a Week & 38 Hours a Week & 47 Hours a Week \\
\hline
\end{tabular}

The methodology of the current analysis consisted of a sample of 18 European apparel Web sites analyzed in pilot research by 36 primarily Belgian students in the spring 2007 semester. The sites were chosen by the authors from the frequency of e-Business dress model and e-CRM functionalities on the sites. The bulk of the sites were also the focus of analysis by the authors and previous students in the 2007 (Lawler et al., 2007) study. The sites were analyzed anonymously and independently by the students in a Bell Net Ethernet Microsoft NT broadband laboratory in a 5 month period of the spring semester as an extra credit program of the course. These students were proactive and realistic Web wired subjects (Ohmae, 2005) for the experiment, as in the previous study. They indicated that they were on the Web 47 hours a week as shoppers or surfers, which was higher than the 38 hours a week of the Belgian students in the 2007 study and the 34 hours a week of the students in the United States in the 2006 study. Twenty-eight (28) of the 36 students shopped on the Web in the prior 3 months of this study, and thirty-two (32) of them surfed on the Web with mobile computing tools. The authors continue to choose students as subjects because of the difficulty of surveying non-student subjects, due to European Union privacy restrictions, though the small sample of 36 students and the students as proxy shoppers on the Web, along with the small number of sites, are limitations of the study.

The 18 sites in the 2007 study were evaluated by the 36 students for design factors in intention to buy apparel on the sites. Each student was allocated a fictitious 1,500 euros to buy products from any number of the 18 sites for a fictitious goal-focused task of being casually dressed for a forthcoming summer vacation in Tunisia. They analyzed each of the sites on the factors of perceived ease of use of the Web site, perceived usefulness of the site, richness of media technology on the site, decision satisfaction with the site, and behavioral intention to return to the site, as defined in Table 1, in which usefulness and ease of use were modified from the original TAM for this shopping study. They also analyzed pre-attitude to Web shopping and post-attitude to Web shopping from their experience of the experiment. They assigned a fine 7 -point scale of $7=$ very high in importance in intention to buy, $6=$ high in importance, $5=$ somewhat high in importance, $4=$ somewhat low in importance, 3 = low in importance, $2=$ very low in importance, and $1=$ not at 
all important in the project shopping task, even if they did not buy on a site. The experiment was done with instructions and an instrument in the French language. The students inserted their evaluations of 7 to 1 on to the instrument, which was formatted by the 18 site names and the 7 design factor names and included blank spaces to include the numeric evaluations. The instrument was footnoted with explanations of the factors that were already discussed extensively in the classroom.

This instrument was evaluated for feasibility in a pilot for the shopping task by 3 instructors and 6 students of the university on 9 of the sites. The 36 students finished the task in July of the spring semester, the third author entered the data into an Excel file, and she furnished the data in the file for examination by the second and first authors of this study.

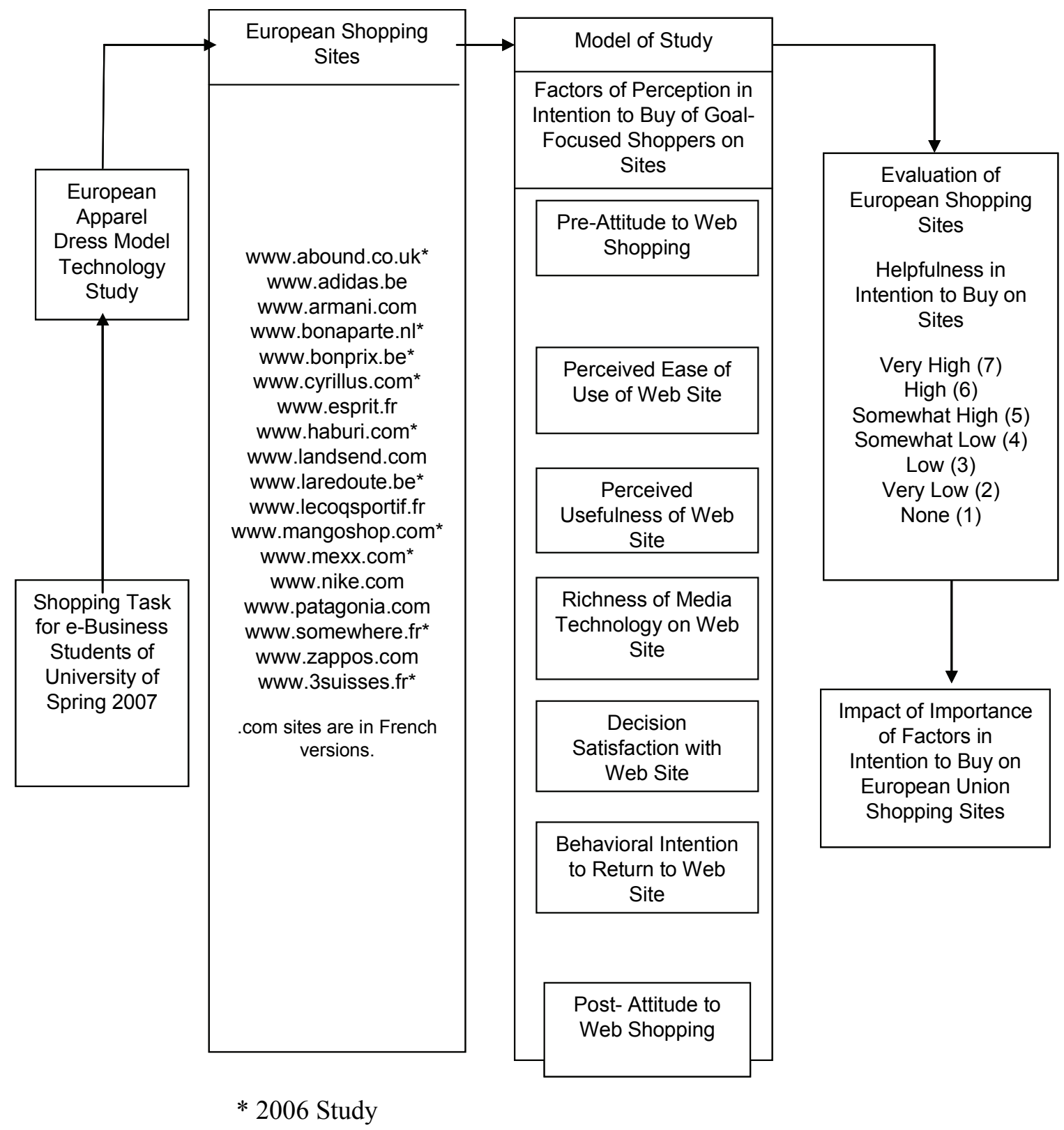

Figure 3: Research Methodology of European Dress Model Technology-2007 Study 
In the examination of the factors, the authors used the Mathwork MATHLAB 7.5 (R2007b) statistical tool box to obtain central tendency (mean and median), variability (standard deviation), relative frequency distribution (histogram), normality testing (skewness, kurtosis, and goodnessof-fit testing), correlation matrices, and hypothesis testing of the importance of richness of media technology (McClave \& Sincich, 2006; Montgomery \& Runger, 2007). The correlation values were evaluated as being weak, moderate, or strong in accordance to the rule that states $0<\mathrm{r} \leq$ 0.5 is weak, $0.5<\mathrm{r}<0.8$ is moderate, and $0.8 \leq \mathrm{r} \leq 1.0$ is strong (DeVore, 1995). Inasmuch as the sample size of the study was small and the central limit theorem was not applied in the study, assumptions were not made about the normality of the population size, but testing was done to determine the condition of normality, in order to aid in the choice of methods applied in the hypothesis testing.

\section{Findings}

As in the previous studies of dress model technology on the Web (Lawler \& Joseph, 2006; Lawler et al., 2007), richness of media technology was of the highest interest to us. As shown in Table 3 of this study, richness of technology had the lowest mean ratings of 3.98 for overall sites and of 3.87 for male shoppers and the second lowest mean rating of 4.08 for female shoppers. Behavioral intention to return had the lowest mean rating of 4.00 for female shoppers. Perceived ease of use and perceived usefulness of the sites had the highest and second highest mean ratings of 5.00 and 4.93, and behavioral intention to return had the second lowest and the lowest mean ratings of 4.04, 4.10 and 4.00 for overall sites, male shoppers, and female shoppers. The differences in perceived usefulness and richness of media technology mean ratings for these shoppers were $0.95,0.98$ and 0.91 respectively, while the absolute differences in richness of technology and behavioral intention to return mean ratings were $0.06,0.23$ and 0.08 respectively.

As shown in Table 3, the highest standard deviations of 1.74 and 1.64 for overall sites were behavioral intention to return and richness of technology, and richness of technology had the second highest deviations for overall sites of 1.64, female shoppers of 1.65, and male shoppers of 1.63 . The lowest standard deviations of 1.34 and 1.25 were mostly perceived ease of use and perceived usefulness. Perceived usefulness had the lowest standard deviations of 1.25 and 1.20 for overall sites and male shoppers, whereas perceived ease of use had a lowest standard deviation of 1.27 for female shoppers.

Almost all (93\%) of the ratings of the overall sites, female shoppers and male shoppers on the factors were $100 \%$ within three standard deviations of their means. All of the ratings on media richness of technology and behavioral intention to return, and almost all (95\%) of the ratings on decision satisfaction, were $100 \%$ within three standard deviations of their means. Ratings of the overall sites, female shoppers and male shoppers on media richness of technology and behavioral intention to return were $100 \%$ within two standard deviations of their means, and $50 \%$ of the sites on perceived ease of use, decision satisfaction and behavioral intention to return were $100 \%$ within two standard deviations of their means. Within one standard deviation of the factor means, perceived usefulness was the highest percentage of ratings for overall sites (81\%), female shoppers $(79 \%)$, and male shoppers $(83 \%)$. 
Table 3: Analysis of Evaluation Factors - Summary

\begin{tabular}{|c|c|c|c|c|c|}
\hline & $\begin{array}{c}\text { Perceived Ease } \\
\text { of Use }\end{array}$ & $\begin{array}{l}\text { Perceived } \\
\text { Usefulness }\end{array}$ & $\begin{array}{c}\text { Media } \\
\text { Richness of } \\
\text { Technology }\end{array}$ & $\begin{array}{c}\text { Decision } \\
\text { Satisfaction }\end{array}$ & $\begin{array}{c}\text { Behavioral } \\
\text { Intention to } \\
\text { Return }\end{array}$ \\
\hline Mean & 5.00 & 4.93 & 3.98 & 4.35 & 4.04 \\
\hline $\begin{array}{l}\text { Standard } \\
\text { Deviation }\end{array}$ & 1.34 & 1.25 & 1.64 & 1.40 & 1.74 \\
\hline $\begin{array}{l}\text { Mean } \\
\text { Male }\end{array}$ & 4.93 & 4.85 & 3.87 & 4.41 & 4.10 \\
\hline $\begin{array}{c}\text { Standard } \\
\text { Deviation } \\
\text { Male }\end{array}$ & 1.42 & 1.20 & 1.63 & 1.28 & 1.66 \\
\hline $\begin{array}{c}\text { Mean } \\
\text { Female }\end{array}$ & 5.05 & 4.99 & 4.08 & 4.30 & 4.00 \\
\hline $\begin{array}{c}\text { Standard } \\
\text { Deviation } \\
\text { Female }\end{array}$ & 1.27 & 1.29 & 1.65 & 1.49 & 1.81 \\
\hline
\end{tabular}

Evaluations: Helpfulness in Intention to Buy on Sites - Very High (7), High (6), Somewhat High (5), Somewhat Low (4), Low (3), Very Low (2), and None (1)

Note: Means and standard deviations of each of the sites are in the Appendix.

Perceived ease of use and perceived usefulness ratings were more highly distributed across rating values of 4,5 and 6 , and 5 and 6 were more frequent than 4 , with 5 as the most frequent. The respective cumulative relative frequencies for ease of use and usefulness for values of 5 and 6 were 0.556 and 0.596 for overall sites, 0.572 and 0.589 for female shoppers, and 0.535 and 0.604 for male shoppers. Richness of media technology and behavioral intention to return ratings were more distributed over rating values of 2, 3, 4 and 5. For richness of technology, 3 and 4 were more frequent for overall sites and female shoppers, and 2 and 3 were more frequent for male shoppers, with 3 as the most frequent for overall sites, female shoppers, and male shoppers; for behavioral intention to return, 4 and 5 were the more frequent, with 5 as the most frequent. The cumulative relative frequencies for richness of technology for values 3 and 4 were 0.431 for overall sites, 0.442 for female shoppers, and 0.451 for male shoppers; the cumulative relative frequencies for behavioral intention to return for values of 4 and 5 were 0.412 for overall sites, 0.369 for female shoppers, and 0.465 for male shoppers. Decision satisfaction ratings were more highly distributed over rating values of 3, 4, 5 and 6 , and 4 and 5 were the more frequent than the others, with the most frequent rating value of 4 for overall sites and male shoppers and 5 for female shoppers. The cumulative relative frequencies for decision satisfaction for values of 4 and 5 were 0.520 for overall sites, 0.470 for female shoppers, and 0.583 for male shoppers.

The cumulative relative frequencies for overall sites and for male shoppers over their range of rating values of highest concentration were perceived ease of use of 0.733 for overall sites and 0.715 for male shoppers, perceived usefulness of 0.806 for overall sites and 0.830 for male shoppers, richness of technology of 0.873 for overall sites and 0.885 for male shoppers, decision satisfaction of 0.844 for overall sites and 0.878 for male shoppers, and behavioral intention to return of 0.827 for overall sites and 0.851 for male shoppers. Behavioral intention to return was the most frequent in the number of value 1 ratings. Relative frequencies for the latter were 0.097 for overall sites and 0.087 for female and 0.106 for male shoppers.

The histogram for overall sites, as shown in Figure 4, and the histograms for female and male shoppers showed that richness of technology was the only factor skewed to the right. The other factors of the study were skewed to the left. 


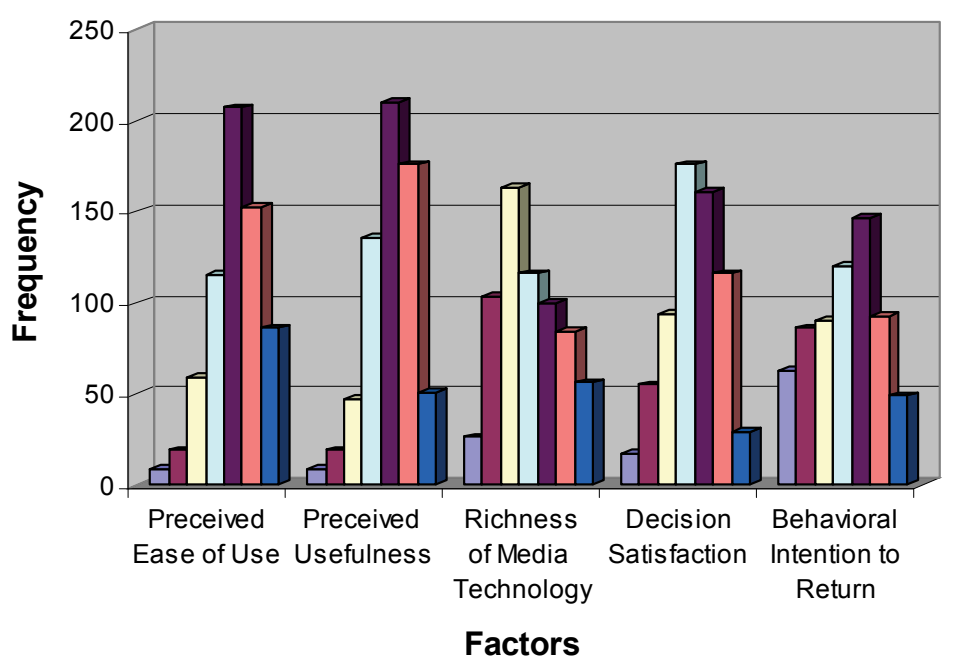

Evaluations

Figure 4: Frequency Distributions of Factors - Summary

Evaluations: Helpfulness in Intention to Buy on Sites - Very High (7), High (6), Somewhat High

(5), Somewhat Low (4), Low (3), Very Low (2), and None (1)

From the histograms, the distributions of the factor ratings were not representative of a population of normal distributions that are similar to apparel Web sites with dress model technology. Inasmuch as the factor ratings were found not likely to be from normal distributions of the population of sites in the study, Wilcoxon two-sided rank sum test and the two-sided sign test were respectively applied to determine whether any two factor ratings were distributions with equal medians from the same population of sites and whether the difference in the pre-attitude and post-attitude factor ratings was a distribution from the population of sites that had a zero median. The null hypothesis of equal medians of ratings of perceived ease of use and perceived usefulness for overall sites, female shoppers and male shoppers; media richness of technology and behavioral intention to return for overall sites and female shoppers; and decision satisfaction and behavioral intention to return for male shoppers could not be rejected at the 0.05 level of significance. In all other instances, the medians of the ratings for any two of the factors were statistically different at the level of significance of 0.05 , as shown in Table 4, with, as examples, richness of technology and perceived usefulness showing statistically different medians at the 0.05 level of significance with an observed probability value of 0.00 for overall sites, female shoppers, and male shoppers; richness of technology and behavioral intention to return showed statistically equal medians at the 0.05 level with a probability value of 0.27 for overall sites and 0.74 for female shoppers.

Table 4: p-Values of Wilcoxon Rank Sum Tests for Medians of Factors - Summary

\begin{tabular}{|c|r|r|r|c|}
\hline & $\begin{array}{c}\text { Perceived Ease of } \\
\text { Use }\end{array}$ & $\begin{array}{c}\text { Perceived } \\
\text { Usefulness }\end{array}$ & $\begin{array}{c}\text { Media Richness of } \\
\text { Technology }\end{array}$ & $\begin{array}{c}\text { Decision } \\
\text { Satisfaction }\end{array}$ \\
\hline $\begin{array}{c}\text { Perceived Ease of } \\
\text { Use }\end{array}$ & & & & \\
\hline $\begin{array}{c}\text { Perceived } \\
\text { Usefulness }\end{array}$ & 0.30 & & & \\
\hline $\begin{array}{c}\text { Media Richness of } \\
\text { Technology }\end{array}$ & 0.00 & 0.00 & & \\
\hline $\begin{array}{c}\text { Decision } \\
\text { Satisfaction }\end{array}$ & 0.00 & 0.00 & & \\
\hline $\begin{array}{c}\text { Behavioral } \\
\text { Intention to Return }\end{array}$ & 0.00 & 0.00 & 0.00 & \\
\hline
\end{tabular}


Finally, the examination of the correlation between any two pairs of factors was shown to be significant at the 0.01 level of significance when compared to the null hypothesis of zero correlation between factors, as shown in Table 5, and for female shoppers and for male shoppers.

Table 5: Correlation Matrix of Factors - Summary

\begin{tabular}{|c|r|r|r|r|}
\hline & $\begin{array}{c}\text { Perceived Ease of } \\
\text { Use }\end{array}$ & $\begin{array}{c}\text { Perceived } \\
\text { Usefulness }\end{array}$ & $\begin{array}{c}\text { Media Richness of } \\
\text { Technology }\end{array}$ & $\begin{array}{c}\text { Decision } \\
\text { Satisfaction }\end{array}$ \\
\hline $\begin{array}{c}\text { Perceived Ease of } \\
\text { Use }\end{array}$ & 0.602 & & & \\
\hline $\begin{array}{c}\text { Perceived } \\
\text { Usefulness }\end{array}$ & 0.176 & 0.278 & & \\
\hline $\begin{array}{c}\text { Media Richness of } \\
\text { Technology }\end{array}$ & 0.452 & 0.510 & & \\
\hline $\begin{array}{c}\text { Decision } \\
\text { Satisfaction }\end{array}$ & 0.433 & 0.346 & \\
\hline $\begin{array}{c}\text { Behavioral } \\
\text { Intention to Return }\end{array}$ & & & & \\
\hline
\end{tabular}

Note: Correlation between any two pairs of evaluation factors is significant at the 0.01 level when compared to the null hypothesis of zero correlation.

The highest correlation values corresponded to coefficient of determination values of 0.421 and 0.362, as shown in Table 6.

Table 6: Coefficient of Determination of Factors - Summary

\begin{tabular}{|c|r|r|r|r|}
\hline & $\begin{array}{c}\text { Perceived Ease of } \\
\text { Use }\end{array}$ & $\begin{array}{c}\text { Perceived } \\
\text { Usefulness }\end{array}$ & $\begin{array}{c}\text { Media Richness of } \\
\text { Technology }\end{array}$ & $\begin{array}{c}\text { Decision } \\
\text { Satisfaction }\end{array}$ \\
\hline $\begin{array}{c}\text { Perceived Ease of } \\
\text { Use }\end{array}$ & 0.362 & & & \\
\hline $\begin{array}{c}\text { Perceived } \\
\text { Usefulness }\end{array}$ & 0.031 & 0.077 & & \\
\hline $\begin{array}{c}\text { Media Richness of } \\
\text { Technology }\end{array}$ & 0.204 & 0.260 & & \\
\hline $\begin{array}{c}\text { Decision } \\
\text { Satisfaction }\end{array}$ & 0.188 & 0.199 & 0.120 & \\
\hline $\begin{array}{c}\text { Behavioral } \\
\text { Intention to Return }\end{array}$ & & & & \\
\hline
\end{tabular}

\section{Discussion}

The factor of media richness of technology for overall sites continued to be less important in the intention of the shopper subjects to buy on the sites of the study.

Fundamental factors of perceived ease of use, perceived usefulness, decision satisfaction, and behavioral intention to return for overall sites were more important in the intention of the shoppers to buy and to continue to buy on the sites, and richness of technology was less important relative to these factors for both the female and male shoppers. This finding confirms literature in the academic field cited in the literature review section of the study that indicates the importance of non-richness of technology factors in intention to buy on Web sites. It clearly confirms literature in the practitioner field indicating the relative non-importance of technological factors, such as richness, as consumers continue to form flash impressions of sites based on non-technological factors. From this finding, the functionality of marketing, sales, and service on the sites is not helped by media richness relative to the other factors in the intention to buy or continue to buy on 
the sites. This finding indicates that e-Business designers and managers of $\mathrm{B} 2 \mathrm{C}$ dress model sites may have to further review the prudence of investment in media technologies in shopping on the Web, which is important in the initiation of managers to integrating multimedia technologies into 3D virtual shopping of Web 2.0 (Hemp, 2006a).

Though the factor of richness of media technology continued to be perceived less important than the fundamental factors of ease of use, usefulness, decision satisfaction and behavioral intention to return, in intention to buy and to continue to buy on the dress model sites in this study, richness was still important in the mix of the non-richness factors. Richness was perceived to be important in shopping on the sites instead of in the stores but, for example, it was not perceived to be optimal in the mix of decision satisfaction and behavioral intention to return nor in the likelihood of relationship. Richness of technology was essentially not perceived as positive as the other factors in influencing shopping. This finding conforms to the literature indicating the importance of the factor of richness in helping in interactivity perceived to be more realistic on the sites than interaction in the physical stores. Investment in the factor of richness is apparently justified by managers in order to leverage innovations in imaging and streaming technologies on the Web, but the investment must be mixed with the other factors, especially ease of use and usefulness, that impact intention to buy on the Web sites. This is important in the need to optimally plan integration of multimedia technologies not only into Web 2.0 sites but into purely Web 1.0 sites of today.

At the same time, managers need to optimize the fundamental factors of ease of use, usefulness, decision satisfaction, and behavioral intention to return, inasmuch as the evaluations were less than high or very high in ratings. This finding conforms to the literature cited in the literature review section, in which the mix of factors of non-richness and richness of technology might be helpful in less or more hedonic or utilitarian tasks on the shopping Web sites. The mix might be helpful in the intention to buy of both non-goal focused and goal focused shoppers. Integration of richness of technology will likely be more helpful to shoppers on the Web if perceived ease of use, perceived usefulness, decision satisfaction and behavioral intention to return were already perceived to be more helpful in importance in the intention to buy and continue to buy on the sites. The investment in Web design of the sites must be mixed in the non-technological and technological factors without further undue influence of the technological factor of richness.

Findings of the new study on the limited importance of the factor of media richness of technology, relative to the factors of non-richness of technology, continued to replicate the results of our prior studies of student shoppers in the European Union (Lawler et al., 2007) and in the United States (Lawler \& Joseph, 2006). Richness of technology was generally not as important for the shoppers. They tended to rate it relatively lower than the non-richness or non-technological factors in the 2007 and 2006 studies and in this new study.

The practical significance of these findings is the business proposition that e-Business designers and managers in the European Union might improve their Web sites by investing less in media richness and more in non-richness. They must not be influenced by the hype of information systems technologists marketing the richness of technology on the Web. They might be more prudent by mixing the investment so that richness of technology is merely one of a number of factors impacting the intention to buy of goal-focused shoppers, and such prudence might lead to more profitable Web sites. 


\section{Conclusion}

The study is constrained in the evaluation of richness of media technology by the small number of students and the students having a fictitious budget as proxy shoppers on the Web. The study is also constrained by the relatively small number of dress model Web sites. The results may be cautiously generalized to the larger population of the Web if the biases of the findings as a pilot research study are considered by readers. Choice of a controlled laboratory of younger aged students as subjects may not encounter conditions and limitations of older aged subjects. Other constraints of the study might be the limited measurement of media richness as multimedia representations of products that enhance or do not enhance the process of apparel shopping on the We. Because of the definitions in the study of richness as the extent of multimedia representations in enhancing the process of shopping and of usefulness as the perception of functionality in enhancing the process of shopping on the Web, there may be a level at which richness and usefulness becomes indistinguishable, where functionality if not information is intertwined in richness. Further distinguishing richness and usefulness might be considered by refining the definition of richness in a new study. Goal-focused shoppers who have limited time to shop on sites may be distracted from too much multimedia richness for the shopping task that usefulness or nonusefulness of the sites may not be distinguishable to them. In a new study, the impact of derived information enacted or enabled, or not enacted nor enabled, by the richness of technology might be further considered by refining the definition of media richness.

In this study, the authors continued an already established measurement of richness or stimuli of technology in shopping consistent with their earlier studies. Dependent on funding from Pace University or the University of Mons-Hainaut, evaluations and hypotheses on e-CRM functionalities and on richness of technology behind the functionalities, from a larger number of student and non-student subjects and of Web sites, may be done in 2008-2010. Refinements of the definition of media richness of technology might be also done in a new study. Funding by European Union government and industry in contrast to America is frequently limited for academic studies (Bounds, 2006; Norton, 2006; Tilford, 2007). This help is crucial to the continuance of the studies since 2005 .

The results of this study of European dress model Web sites is confirming richness of media technology as relatively lower in importance in the intention of to buy apparel products on the sites. Perceived ease of use, perceived usefulness, decision satisfaction and behavioral intention to return are suggested to be higher in importance in the intention of goal-focused customers to buy on the bulk of the sampled sites in the study. Results correspond to earlier studies of both European Union and American Web sites. The results of this study also advance e-Commerce research by contrasting media richness to established factors of usefulness and ease of use from TAM research. The extension of the TAM factors to this study of richness and the evaluation of the TAM factors relative to richness reinforced the results of the earlier studies that richness of technology is relatively lower in importance in shopping on the Web. This was useful to show in this new study. Research of media and of specific e-CRM marketing, sales and service technologies on the sites in tandem is the next step. The results of this study will be helpful to designers of sites and to managers in the sustainability of e-Business strategies in the European Union and the United States.

\section{Acknowledgements}

The authors continue to be grateful to the third author for the data from the European Commission in Brussels and to the e-Business students of the University of Mons-Hainaut, who have helped in our studying of the European Union shopping sites in 2007 and 2006. 


\section{References}

Bergeron, B. (2001). The eternal e-customer: How emotionally intelligent interfaces can create longlasting customer relationships. New York: McGraw-Hill.

Bezjian-Avery, A. A., \& Calder, B. (1998). New media interactive advertising versus traditional advertising. Journal of Advertising Research, 38(4), 23-32.

Blau, J. (2007, February 1). European Union to offer 1.2 billion euros for information technology and telecommunication research in 2007. InfoWorld, 1-4.

Bounds, A. (2006, October 11). European Union and industry shun MIT-style research project. Financial Times, p. 5.

Brinker, S. (2007, April 2). Corporate sites not the best for post-click marketing. BtoB, p. 10.

Byrnes, N. (2007, December 17). More clicks at the bricks: How retail stores are scrambling to catch up with shoppers empowered by the web. Business Week, 052 .

Cane, A. (2007, November 7). Visual messages escape confines of the classroom. Financial Times, p. 4.

Carlin, D. (2007, March 28). Europe tops world in network readiness. Business Week, 1-2.

Chen, H-M, Chen, Q., \& Kazman, R. (2007). The affective and cognitive impacts of perceived touch on on-line customer intention to return in the web-based e-CRM environment. Journal of Electronic Commerce in Organizations, 5(1), 2-7.

Cheung, C., Chan, G., \& Limayem, M. (2005). A critical review of on-line consumer behavior: Empirical research. Journal of Electronic Commerce in Organizations, 3(4), 1-19.

Coyle, J. R., \& Thorson, E. R. (2001). The effects of progressive levels of interactivity and vividness in web marketing sites. Journal of Advertising, 30(3), 65-78.

Danziger, J. (2006). Building a drag-and-drop shopping cart with AJAX. AJAX Systems, Premier, 16-19.

Davis, F. D. (1989). Perceived usefulness, perceived ease of use, and user acceptance of information technology. MIS Quarterly, 13(3), 319-340.

DeVore, J. (1995). Probability and statistics for engineering and the sciences (4th ed.). New York: Duxbury Press.

Durst, S. (2006, December). Shoe in: Zappos has become the number 1 footwear retailer on the Web by making customer service a competitive weapon. Business 2.0, 54.

Eisenberg, A. (2007, November 25). A web tour will show stores from the inside out. The New York Times, Sunday Business, p. 3.

European Commission: Enterprise and Industry Directorate General. (2006). E-business watch: A pocketbook of e-business indicators.

European Union to invest $\$ 9$ billion in information communication technology research. (2006, November 21). Government Technology, 1-4.

Fiore, A. M., \& Jin, H-J. (2003). Influence of image interactivity on approval responses towards an on-line retailer. Internet Research: Electronic Networking Applications \& Policy, 13(1), 39, 44.

Fitzsimmons, J. A., \& Fitzsimmons, M. J. (1997). Service management: Operations, strategy, and information technology, second edition. New York: Irwin / McGraw-Hill.

Gardner, W. D. (2006, December 21). Europe earmarks \$11 million for advanced multimedia search platform research. Information Week, p. 10.

Garrity, E. J., Glassberg, B., Kim, Y. J., Sanders, G. L., \& Shin, S. (2005). An experimental investigation of web-based information system success in the context of electronic commerce. Decision Support Systems, 39(3), 485-503. 
Gharbi, J-E., \& Soltani, I. (2007). Telepresence, flow, perceived value and e-loyalty. Proceedings of the International Conference on Computing and e-Systems, Hammamet, Tunisia, March 12-14, 216.

Goldsmith, R. E. (2000). How innovativeness differentiates on-line buyers. Quarterly Journal of Electronic Commerce, 1(4), 223-333.

Greenemeier, L. (2005, August 15/22). The web moves. Information Week, 47-50.

Hemp, P. (2006a, October). Are you ready for e-tailing 2.0? Harvard Business Review, 28.

Hemp, P. (2006b, June). Avatar-based marketing. Harvard Business Review, 48-57.

Hof, R. (2007, April 16). The coming virtual web. Business Week, 1-2.

Hoffman, D. L., \& Novak, T. P. (1996). Marketing in hypermedia computer-mediated environments: Conceptual foundations. Journal of Marketing, 60(3), 50-68.

Information communication technology drives 50\% of European Union growth. (2007, March 30). Government Technology, 1-4.

Kim, J., \& LaRose, R. (2004). Interactive e-commerce: Promoting consumer efficiency or impulsivity? Journal of Computer Mediated Communication, 10(1).

Klein, L. R. (2003). Creating virtual product experiences: The role of telepresence. Journal of Interactive Marketing, 17(1), 41-54.

Lawler, J., \& Joseph, A. (2006). A study of apparel dress model technology on the web. Journal of Information, Information Technology, and Organizations, 1, 59-73. Retrieved from http://jiito.org/articles/JIITOv1p059-073Lawler20.pdf

Lawler, J., Vandepeutte, P., \& Joseph, A. (2007). An exploratory study of apparel dress model technology on European web. Journal of Information, Information Technology, and Organizations, 2, 31-46. Retrieved from http://jiito.org/articles/JIITOv2p031-046Lawler45.pdf

Li, H., Daugherty, T., \& Biocca, F. (2001). Characteristics of virtual experience in electronic commerce: A protocol analysis. Journal of Interactive Marketing, 15(3), 13-30.

Liu, C., Armett, K. P., Capella, L. M., \& Taylor, R. D. (2001). Key dimensions of web design quality as related to consumer response. Journal of Computer Information Systems, 42(1), 70-82.

Massad, N., Heckman, R., \& Crowston, K. (2006). Customer satisfaction with electronic service encounters. International Journal of Electronic Commerce, 10(4), 78.

McClave, J. \& Sincich, T. (2006). A first course in statistics (9th ed.). Upper Saddle River, New Jersey: Pearson Prentice Hall.

McConnon, A. (2007, August 13). Just ahead: The web as a virtual world. Business Week, 62-63.

McCoy, S., Everard, A., Polak, P., \& Galletta, D. F. (2007). The effects of on-line advertising. Communications of the ACM, 50(3), 84-88.

McDonald, D. (2006, November). Sole purpose: In delivering top-notch customer service, on-line shoe retailer Zappos keeps its information technology fast, simple and open. CIO Insight, 42-51.

Mitchell, R. L. (2006, September 25). Graphical user interface gets a makeover. Computerworld, 23-26.

Montgomery, D. \& Runger, G. (2007). Applied statistics and probability for engineers (4th ed.). New York: John Wiley \& Sons.

Nielsen, J. (2007, March 15). Things I have learned. CIO, 64.

Newitz, A. (2007, September 5). Virtual reality will enhance real-world experience. New Scientist Tech, 1.

Norton, K. (2006, September 15). Spinning gold from good ideas. Business Week, 2.

Novak, T. P., Hoffman, D. L., \& Yung, Y-F (1999, October 7). Measuring the customer experience in online environments: A structural modeling approach. Sloan Center for Internet Retailing, 1-4. 
O'Connor, F. (2007, March 28). Survey shows United States slipping globally in information technology use. InfoWorld, 1-4.

Ohmae, K. (2005). The next global stage: Challenges and opportunities in our borderless world (pp. 176177). Upper Saddle River, New Jersey: Wharton School Publishing.

Olson, E. (2007, December 2). If the shoe fits, wear it. If not, design one that does. The New York Times, Sunday Money, p. 7.

Orman, L. V. (2007). Consumer support systems. Communications of the ACM, 50(4), 49-54.

Pratt, M. K. (2007, May 28). Web site return-on-investment. Computerworld, 30.

Pullman, M. E., \& Gross, M. A. (2004). Ability of experience design elements to elicit emotions and loyalty behaviors. Decision Sciences, 35(3), 553.

Rayport, J. F. (2007, February). Demand-side innovation: where information technology meets marketing. Optimize, 36-40.

Schneider, J. (2007, December). 5 innovations changing retail. Baseline, 28.

Schonfeld, E. (2007, March). Make way for must stream television. Business 2.0, 95-97.

Scott, M. (2007, November 6). Global competitors: The super markets, Business Week, 1-2.

Sharp, J. H. (2006). Development, extension, and application: A review of the technology acceptance model. Proceedings of the Information Systems Education Conference, Dallas, Texas, November 3, 7.

Srinivasan, S. S., Anderson, R., \& Ponnavolu, K. (2002). Customer loyalty in e-commerce: An exploration of its antecedents and consequences. Journal of Retailing, 78(1), 41-50.

Tilford, S. (2007, March 10-11). Get with it, Europe. International Herald Tribune, 5.

Valacich, J. S., Parboteeah, D. V., \& Wells, J. D. (2007). The on-line consumer's hierarchy of needs. Communications of the ACM, 50(9), 88.

Van Der Heijden, H. (2004). User acceptance of hedonic information systems. MIS Quarterly, 28(4), 695704.

Venkatesh, V., Morris, M., Davis, G., \& Davis, F. (2003). User acceptance of information technology: Toward a unified view. MIS Quarterly, 27(2), 425-478.

Wailgum, T. (2006, November 15). Ready for the holiday traffic? CIO, 22.

Wolfendale, J. (2007). My avatar, my self: Virtual harm and attachment. Ethics and Information Technology, 9, 114.

Wolfinbarger, M., \& Gilly, M. C. (2001). Shopping on-line for freedom, control, and fun. California Management Review, 43(2), 34-55.

World's most innovative countries. (2007, March 5). Government Technology, 1-3.

Worldwide internet audience has grown 10\% since last year. (2007, March 6). Government Technology, 13. 


\section{Appendix: \\ European Dress Model Sites of Study - Analysis of Evaluation Factors}

\begin{tabular}{|c|c|c|c|c|c|}
\hline & $\begin{array}{c}\text { Perceived } \\
\text { Ease of Use }\end{array}$ & $\begin{array}{l}\text { Perceived } \\
\text { Usefulness }\end{array}$ & $\begin{array}{l}\text { Media Richness of } \\
\text { Technology }\end{array}$ & $\begin{array}{c}\text { Decision } \\
\text { Satisfaction }\end{array}$ & $\begin{array}{l}\text { Behavioral } \\
\text { Intention to } \\
\text { Return }\end{array}$ \\
\hline \multicolumn{6}{|l|}{ Site \#1 } \\
\hline Mean & 5.50 & 5.36 & 3.86 & 4.47 & 4.00 \\
\hline $\begin{array}{l}\text { Standard } \\
\text { Deviation }\end{array}$ & 0.85 & 0.99 & 1.38 & 1.50 & 1.76 \\
\hline \multicolumn{6}{|l|}{ Site \#2 } \\
\hline Mean & 5.06 & 5.31 & 3.22 & 4.11 & 3.92 \\
\hline $\begin{array}{l}\text { Standard } \\
\text { Deviation }\end{array}$ & 0.83 & 0.67 & 1.51 & 1.06 & 1.38 \\
\hline \multicolumn{6}{|l|}{ Site \#3 } \\
\hline Mean & 4.17 & 4.31 & 2.92 & 4.06 & 3.67 \\
\hline $\begin{array}{l}\text { Standard } \\
\text { Deviation }\end{array}$ & 1.18 & 1.31 & 1.23 & 1.41 & 1.82 \\
\hline \multicolumn{6}{|l|}{ Site \#4 } \\
\hline Mean & 5.79 & 5.44 & 4.15 & 4.82 & 4.88 \\
\hline $\begin{array}{l}\text { Standard } \\
\text { Deviation }\end{array}$ & 1.01 & 0.93 & 1.26 & 1.06 & 1.89 \\
\hline \multicolumn{6}{|l|}{ Site \#5 } \\
\hline Mean & 5.66 & 5.06 & 3.31 & 4.49 & 4.46 \\
\hline $\begin{array}{l}\text { Standard } \\
\text { Deviation }\end{array}$ & 0.97 & 0.87 & 1.18 & 1.31 & 1.56 \\
\hline \multicolumn{6}{|l|}{ Site \#6 } \\
\hline Mean & 5.29 & 4.83 & 4.54 & 3.94 & 3.91 \\
\hline $\begin{array}{l}\text { Standard } \\
\text { Deviation }\end{array}$ & 1.30 & 1.56 & 1.27 & 1.45 & 1.62 \\
\hline \multicolumn{6}{|l|}{ Site \#7 } \\
\hline Mean & 5.23 & 4.69 & 3.29 & 4.23 & 3.69 \\
\hline $\begin{array}{l}\text { Standard } \\
\text { Deviation }\end{array}$ & 1.33 & 1.08 & 1.30 & 1.40 & 1.59 \\
\hline \multicolumn{6}{|l|}{ Site \#8 } \\
\hline Mean & 4.80 & 4.46 & 3.23 & 4.09 & 3.23 \\
\hline $\begin{array}{l}\text { Standard } \\
\text { Deviation }\end{array}$ & 1.28 & 1.31 & 1.03 & 1.04 & 1.50 \\
\hline Site \#9 & & & & & \\
\hline Mean & 5.19 & 5.14 & 3.92 & 4.64 & 4.44 \\
\hline $\begin{array}{l}\text { Standard } \\
\text { Deviation }\end{array}$ & 0.89 & 0.96 & 1.34 & 1.31 & 1.50 \\
\hline
\end{tabular}




\begin{tabular}{|c|c|c|c|c|c|}
\hline Site \#10 & & & & & \\
\hline Mean & 5.44 & 5.44 & 4.67 & 4.83 & 4.89 \\
\hline Standard & & & & & \\
\hline Deviation & 1.23 & 1.08 & 1.29 & 1.21 & 1.72 \\
\hline Site \#11 & & & & & \\
\hline Mean & 4.39 & 4.19 & 3.89 & 3.75 & 3.67 \\
\hline Standard & & & & & \\
\hline Deviation & 1.23 & 1.33 & 1.95 & 1.54 & 1.79 \\
\hline Site \#12 & & & & & \\
\hline Mean & 4.50 & 5.39 & 5.94 & 4.83 & 4.92 \\
\hline Standard & & & & & \\
\hline Deviation & 1.80 & 1.50 & 1.39 & 1.66 & 1.83 \\
\hline Site \#13 & & & & & \\
\hline Mean & 4.22 & 4.64 & 5.58 & 4.39 & 4.22 \\
\hline Standard & & & & & \\
\hline Deviation & 1.12 & 1.29 & 1.63 & 1.27 & 1.66 \\
\hline Site \#14 & & & & & \\
\hline Mean & 4.92 & 5.14 & 4.08 & 4.36 & 3.42 \\
\hline $\begin{array}{l}\text { Standard } \\
\text { Deviation }\end{array}$ & 1.13 & 0.99 & 1.66 & 1.25 & 1.38 \\
\hline Site \#15 & & & & & \\
\hline Mean & 3.37 & 3.91 & 3.00 & 3.26 & 2.74 \\
\hline Standard & & & & & \\
\hline Deviation & 1.54 & 1.52 & 1.48 & 1.36 & 1.70 \\
\hline Site\#16 & & & & & \\
\hline Mean & 5.74 & 5.40 & 3.97 & 5.03 & 5.06 \\
\hline $\begin{array}{l}\text { Standard } \\
\text { Deviation }\end{array}$ & 0.95 & 1.01 & 1.44 & 1.18 & 1.55 \\
\hline Site\#17 & & & & & \\
\hline Mean & 4.81 & 4.58 & 4.83 & 4.42 & 3.97 \\
\hline $\begin{array}{l}\text { Standard } \\
\text { Deviation }\end{array}$ & 1.49 & 1.50 & 1.73 & 1.73 & 1.87 \\
\hline Site\#18 & & & & & \\
\hline Mean & 5.89 & 5.36 & 3.56 & 4.50 & 4.03 \\
\hline $\begin{array}{l}\text { Standard } \\
\text { Deviation }\end{array}$ & 0.85 & 0.83 & 1.36 & 1.46 & 1.48 \\
\hline
\end{tabular}

Note: Results on the sites are noted by numbers, in order to ensure continued confidentiality of the firms in the study. 


\section{Biographies}

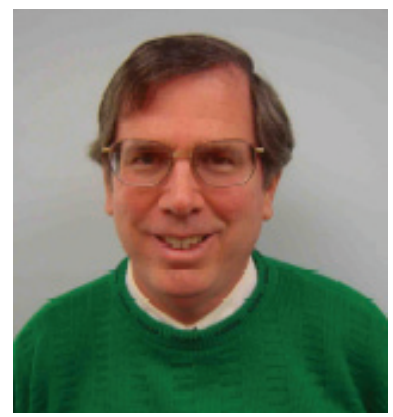

Dr. James Lawler, Principal Author, is Associate Professor of Information Systems, in the Information Systems Department, of The Ivan G. Seidenberg School of Computer Science and Information Systems, at Pace University, in New York City, USA. His interests in research include competitive e-Commerce Web design methods and eCommerce and customer relationship management (CRM) technologies on the Web, in the United States, Europe and northern Africa. He is a Visiting Professor of Information Systems, at the University of Mons-Hainaut, in Mons, Belgium.

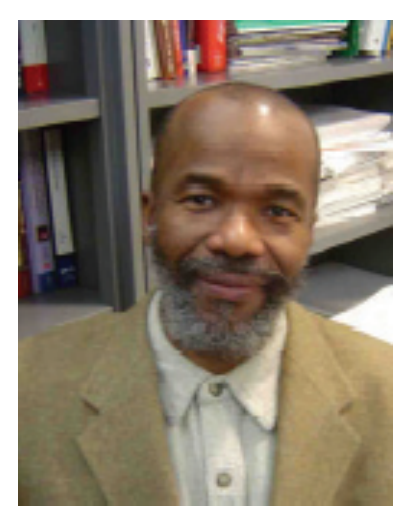

Dr. Anthony Joseph is Associate Professor of Computer Science, in the Computer Science Department, of the Seidenberg School, at Pace University, New York. His interests in research include digital signal processing techniques in spectral and time-frequency studies and active learning and collaborative learning techniques. He is a frequent collaborator with Dr. Lawler and Dr. Vandepeutte on research and on statistical techniques.

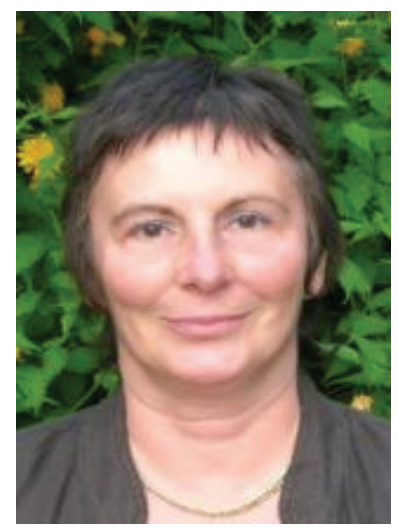

Dr. Pascale Vandepeutte is Lecturer of Computer Science and eBusiness, at the University of Mons-Hainaut, Mons, Belgium. Her interests in research include e-Commerce methodologies and mobile computing and privacy regulations and technologies in the European Union. She is a frequent collaborator with Dr. Lawler on e-Commerce research in Europe and northern Africa. 